\title{
Influence of Annealing Temperature on Electrical Properties of Unmodified Bentonite
}

\author{
Sevinj R. Imanova, Shamistan M. Hasanli, Ulkar F. Samadova, Rasim K. Guseynov, Ulviyye M. \\ Safarzade
}

\begin{abstract}
In this work, influence of annealing temperature on the electrical properties of unmodified bentonite has been investigated. It is concluded that, by the increase of annealing temperature, the values of permittivity and conductivity are decreased, but the electric resistance and the density of the bentonite are increased. It is also shown that the basic reason for this is the presence of water molecules and alkaline oxides such as $\mathrm{Na}_{2} \mathrm{O}, \mathrm{K}_{2} \mathrm{O}$ in bentonite.
\end{abstract}

Index Terms-Polymer; Bentonite; Composite; Montmorillonite; Nanocomposite; Conductivity; Resistivity.

\section{INTRODUCTION}

In recent years, extensive research processes of composite materials based on polymers and natural layered silicates have been conducted. This class of new nanocomposites has synergistic properties of the initial components. The singularity of their architectural design is due to the ability of organic phase to capture the nanoparticles into a kind of "traps" or polymer network.

At the same time, many natural silicates, which include, for example, hectorite and montmorillonite (mica-type structure) are comprised of alternating layers of cation and a negatively charged layer silicate. Such layers of "master" together with controlled systems of percolation pores and channels easily form inclusion compounds that's also true in the case of monomer molecules «guests» [1]-[7]. At the same time, there are almost no materials in the literature devoted to the electrophysical characteristics of bentonite. This work is devoted to the study of the influence of annealing temperature on the electrical properties and IR spectra of unmodified bentonite.

\section{MATERIAL AND METHOD}

The test samples were obtained from the finely divided bentonite in the form discs (washers) with $1.5 \mathrm{~mm}$ thickness and $7 \mathrm{~mm}$ diameter. The discs were extruded at room

Published on June 27, 2018

S. R. Imanova is with the Ganja State University, Shah Ismayil Khatai Ave, Ganja (e-mail: sevinc_imanova81@mail.ru).

S. M. Hasanli is with Institute of Physics, National Academy of Sciences of Azerbaijan, pr. H.Javid 131, Baku, AZ_1143 Azerbaijan (email: hasanli_sh@rambler.ru).

U. F. Samedova is with Institute of Physics, National Academy of Sciences of Azerbaijan, pr. H.Javid 131, Baku, AZ_1143 Azerbaijan (email: neytrino7@gmail.com).

R. K. Guseynov is with the Ganja State University, Shah Ismayil Khatai Ave, Ganja

U. M. Safarzade is with Institute of Physics, National Academy of Sciences of Azerbaijan, pr. H.Javid 131, Baku, AZ_1143 Azerbaijan (email: seferzade.ulviyye@gmail.com). temperature without heating under pressure $(1 \mathrm{GPa})$. Then four of the discs were subjected to a thermal annealing at $400{ }^{\circ} \mathrm{C}, 600^{\circ} \mathrm{C}, 800^{\circ} \mathrm{C}$ and $1000{ }^{\circ} \mathrm{C}$. Annealing of the discs was conducted in an air atmosphere furnace such a RH15/15. Disc annealing was performed with the help of a special program. To investigate the electrical characteristics, both sides of the pressed discs were coated by measuring electrodes of silver paste.

For the study Dashsalahlinsky (Azerbaijan) bentonite was used.VAC dielectric properties and electrical resistance was tested on all samples. The measurements of capacitance and dielectric loss factor $\mathrm{D}(\operatorname{tg} \delta)$ were carried out by means of digital gauges immittance E7-20 (at frequencies of 25-106 $\mathrm{Hz}$ ). The sample was applied to a measuring voltage of $1 \mathrm{~V}$. The measuring instrument selects automatically the characteristics of the reactivity of equivalent circuit of the samples when the accuracy measurement $\varepsilon$ and $\mathrm{D}(\operatorname{tg} \delta)$ was 3 , and $5 \%$, respectively. The values of the real and imaginary parts of the permittivity ( $\varepsilon^{\prime}$ 'and $\varepsilon$ "), as well as the value of conductivity of the samples were determined from the measurement results of capacitance $\mathrm{C}$ and the dielectric loss factor using the formulas

$$
\begin{aligned}
& C=\frac{\varepsilon \varepsilon_{0} S}{d}, \quad \varepsilon^{s}=\frac{\varepsilon}{{\sqrt{1+D^{2}}}^{x}} \quad \varepsilon^{s s}=\frac{\varepsilon}{\sqrt{1+D^{2}}} D \\
& \sigma=2 \pi f \varepsilon^{s} \varepsilon_{0} D
\end{aligned}
$$

Where, D-dielectric loss factor, $\varepsilon$ '-real part of the dielectric permittivity, $\varepsilon$ "- imaginary part of the dielectric constant, C-capacitance of the capacitor, $\varepsilon_{0}=8,85 * 10^{-12} \mathrm{~F} /$ m.

The results of calculations are shown in Fig. 1-6. From analysis of the graphics the following conclusions can draw:

1) Independently of the annealing temperature, the change of the dielectric constant $(\varepsilon)$ from the frequency has a relaxation character, which is expressed by a monotone decrease of $(\varepsilon)$ Fig.1, with increase of frequency. This character of the variation corresponds to the dipole and the migration polarizations.

2) The maximum value of dielectric permittivity is observed on no annealed sample (50000) and the lowest value for the annealed sample at $1000^{\circ} \mathrm{C}$ (39pF).

3) For no annealed sample, by increasing frequency D sharply decreases, reaches the minimum value at $\mathrm{f}$ $=100 \mathrm{kHz}$ then with increase of frequency monotonically increases.

4) For the sample annealed at $500^{\circ} \mathrm{C}$ with the increase of frequency $\mathrm{D}$ increases, reaching the maximum 
value at $\mathrm{f}=100 \mathrm{kHz}$, and then it monotonically decreases Fig. 2.

5) For the samples annealed at $800^{\circ} \mathrm{C}$ and $1000^{\circ} \mathrm{C}$ dependences $D=f(F)$ have the same, namely, particulate character Recession $D=f(F)$ depends on the frequency which is explained by delay of dipoles and reduce of the number of particles participating in polarization.

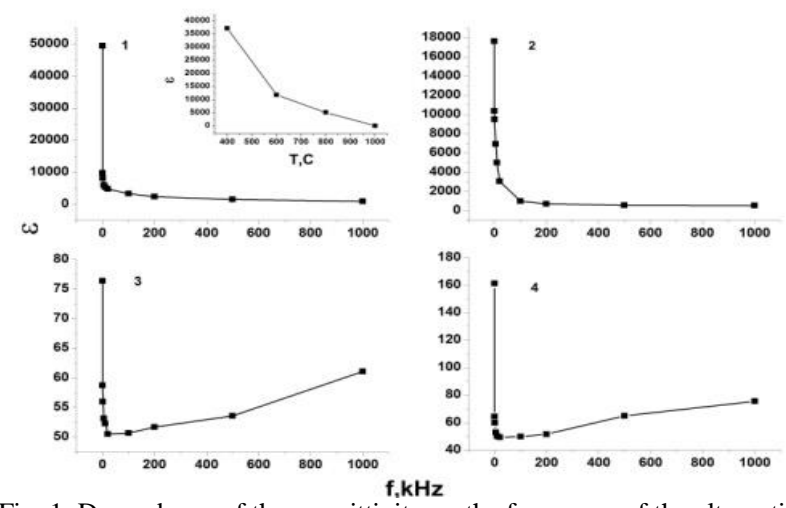

Fig. 1. Dependence of the permittivity on the frequency of the alternating field: 1 -unmodified, $2-\mathrm{T}=500 \mathrm{C}, 3-\mathrm{T}=800 \mathrm{C}, 4-\mathrm{T}=1000 \mathrm{C}$. $5-\varepsilon=\mathrm{f}(\mathrm{T})$.

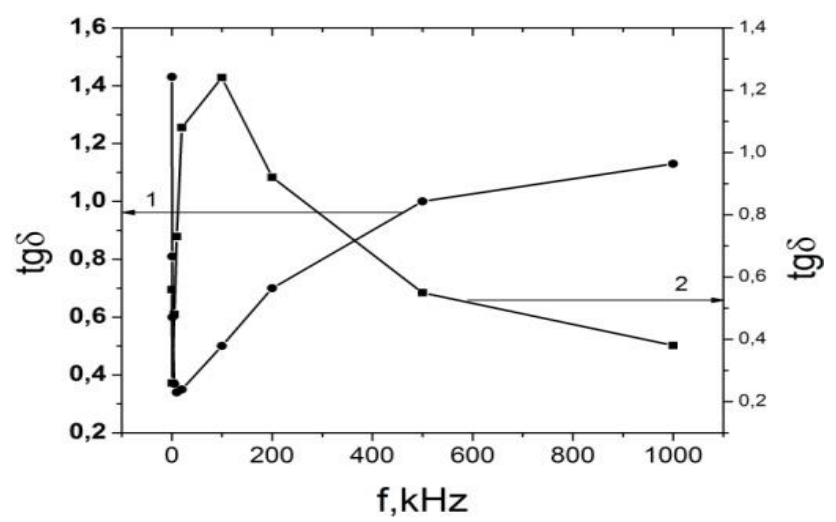

Fig. 2. Dependence of dielectric loss for unmodified bentonite on frequency: $1-\mathrm{T}=25{ }^{\circ} \mathrm{C}, \mathrm{T}=500{ }^{\circ} \mathrm{C}$.

From Fig. 3, it is seen that the dependence of the value of current (VAC) on the applied voltage observed on the investigated samples has complex character.

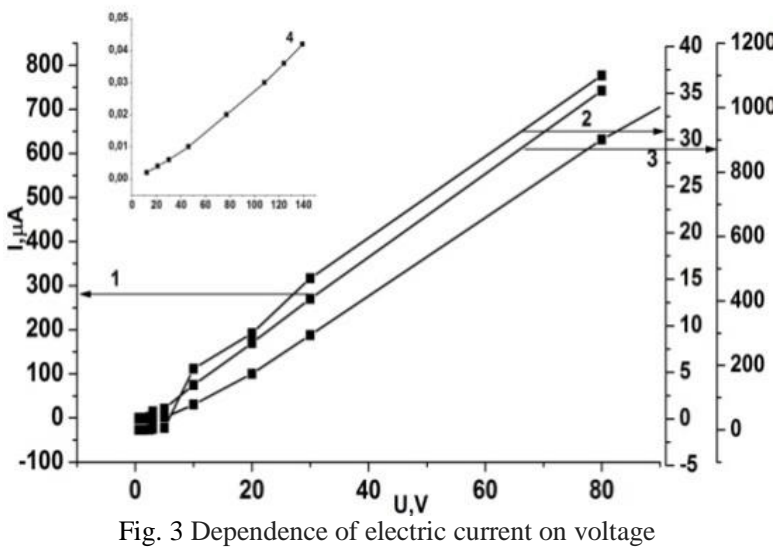

Fig. 3 Dependence of electric current on voltage

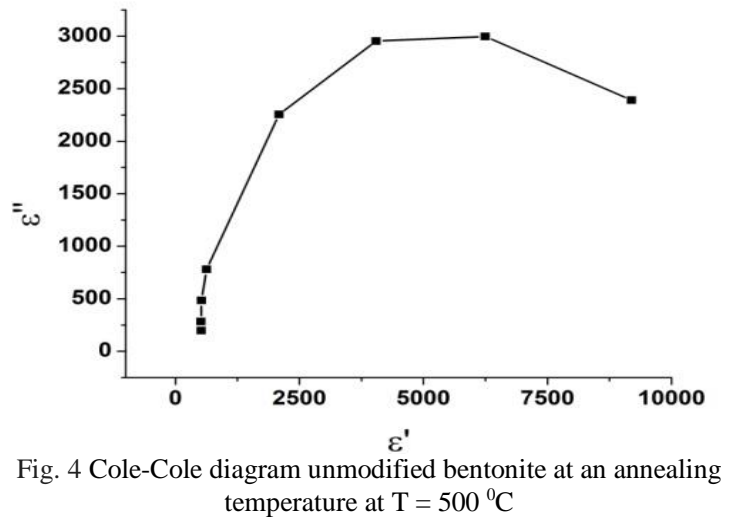

Thus, for no annealed sample VAC is nonlinear, in other words with increase of applied voltage the value of current increases and changes in the order of 2-5, for annealed samples VAC has linear character.

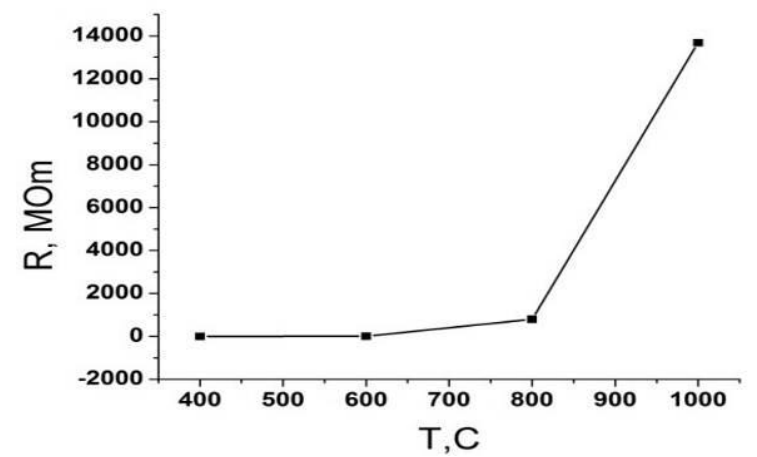

Fig. 5. Dependence electrical resistance of the annealing temperature

It should be noted that the observed dependence $\varepsilon "=\mathrm{f}$ $\left(\varepsilon^{\prime}\right)$ (semicircle) Fig. 4. At annealing temperature at $\mathrm{T}=500$ ${ }^{0} \mathrm{C}$ that is typical for dielectric of low conductivity, is not the same for ion-exchange materials [7]. The value of electrical resistance increases rapidly with increase of annealing temperature (Fig. 5).

\section{RESULTS AND DISCUSSION}

Note that, the production of polymer compositions with special physical properties are largely depend on the nature of the filler, the shape, size and character of the particle distribution as well as the degree of interaction between the components.

The nature of the aggregation of filler particles, conditions of crystallization and other factors change the morphology of the polymer matrix, and as the result the composites obtained on their basis acquire unique properties, which lead to an increase in their practical application possibilities. This is due to the fact that, unlike traditional non-linear devices, they contain symmetrical current-voltage (I-V).

The development of physical chemistry and technology of composite materials, which are in most cases filled with linear and cross-linked polymers, requires clarification of our ideas about the nature of their nearby orderliness and their above molecular order.

Besides that, there is not sufficient knowledge of contact phenomenon, the change the electro physical and electro active properties of the heterogeneous systems polymerfiller, especially interfacial phenomena 
Before discussing the experimental results, we should note the following features of the crystal structure of clay minerals. According to these papers [4]-[6], the clay mineral includes two layers of silicon-oxygen tetrahedral, facing each other by their peaks, that on both sides covered by the layer of Aluminohydroxyl octahedral, which in general appears to be a three-layer packet (2: 1).

The thickness of the elementary packet is $0.96 \mathrm{~nm}$. If you look at the structure of montmorillonite, it can be seen that the nanoscale related only to the interplanar distances, whereas the length and width of these layers can be up to a few microns. A characteristic feature of the montmorillonite structure is that the molecules of water and other polar molecules, for example some organic molecules, can penetrate between the structural layers, causing the expansion of the lattice.

Montmorillonite clays possess a certain capacity for cation exchange. This indicator determines the amount of exchangeable cations in the layered silicate (mg-equivalent), capable of being replaced by cations of another type in terms of 100 grams of clay.

Montmorillonite has the largest cation exchange capacity (up to 90-120 mg.eq / $100 \mathrm{~g}$ of dry clay) among layered silicates. From the above statements the experimental results can be explained by the following way.

The large value of dielectric constant (or electrical conductivity) and the dielectric loss in the initial bentonite is due to the fact that under the influence of thermal motion the weakly bound ions of alkali metal oxides $\left(\mathrm{Na}_{2} \mathrm{O}, \mathrm{K}_{2} \mathrm{O}\right)$ can come off from the floor fixing points and move from one cell spatial grid to another.

At the same time, ion-relaxation polarization is enhanced, as a result of this, the number of ions involved in the electrical conductivity increases. Moreover, the smaller the ion radius, the greater mobility, the greater their contribution to the conductivity.

Since the sodium ion has a smaller radius than the potassium ion, respectively, it will have more influence on the electrical conductivity of bentonite.

According to the work [6] and [8], the presence of water molecules in the bentonite also greatly affects the electrical properties of the bentonite. In the works [6] and [8], it has been shown experimentally that with increasing annealing temperature, the number of water molecules is greatly decreased and as a result of which the dimensions of the mineral lattice is reduced to $98 \mathrm{~nm}$.

Note also that, the annealing temperature also affects the density of the samples, namely, by increasing annealing temperature, the density of the investigated samples is increased (see Fig. 6).

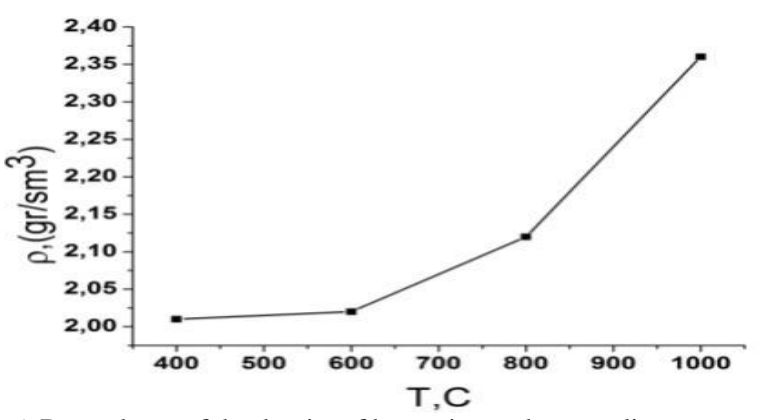

Fig.6. Dependence of the density of bentonite on the annealing temperature
In this way, by the thermal annealing the material with a high resistance $\left(10^{10} \mathrm{ohms}\right)$ is obtained that can be successfully used in various fields of the electronic industry.

From the analysis of the IR spectrum of Fig. 6 a, b the presence of various structural groups in bentonite, namely, stretching vibrations of $\mathrm{OH}$ groups in the 3400-3600 range, stretching vibrations of $\mathrm{Si}-\mathrm{O}-\mathrm{Si}$ and $\mathrm{Si}-\mathrm{O}-\mathrm{Al}$ at 1037 , and deformation vibrations of $\mathrm{H}_{2} \mathrm{O}$ at 1635 , and $\mathrm{Al}-\mathrm{OH}-\mathrm{Mg}$ at 843 , etc. We note that the IR spectrum data are well combined with the data of [9] and [10]. From a comparison of the IR spectra (Fig. 6) it is clear that at the annealing temperature $\mathrm{T}=1000{ }^{\circ} \mathrm{C}$ there are no reflexes associated with water molecules and $\mathrm{OH}$ groups. Taking into account the fact that water has a high conductivity, its absence at the annealing temperature $\mathrm{T}=1000{ }^{\circ} \mathrm{C}$ leads to a decrease in the conductivity of bentonite.

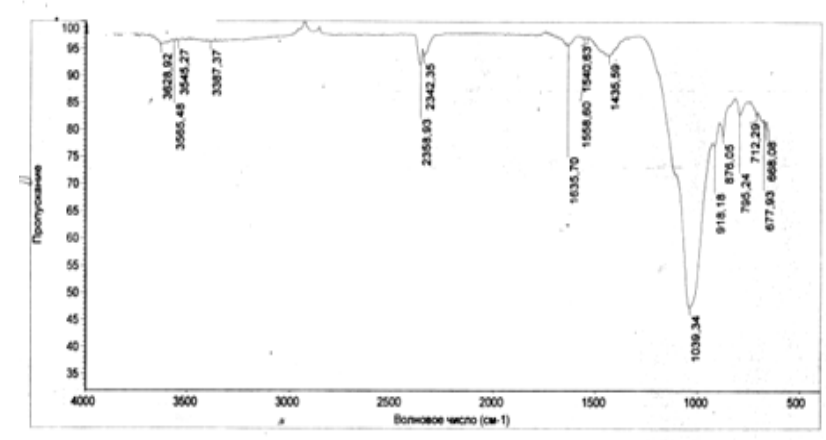

a)

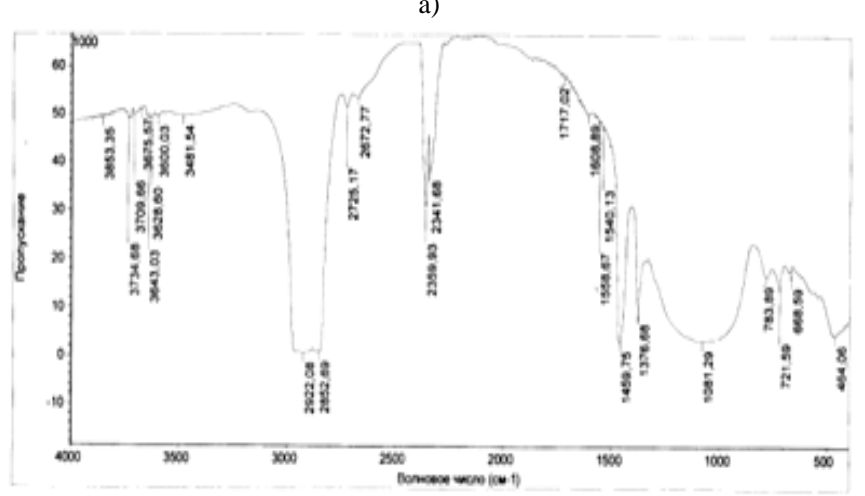

b)

Fig. 7. Infrared spectra: a) unburned bentonite, b) annealed bentonite

This, in turn, according to the formula leads to a decrease in the dielectric constant, dielectric losses and to the growth of electrical resistance.

It should be noted that for materials used in high voltage installations, especially in high-voltage and high-frequency devices, it is important that these materials have small values of dielectric loss and dielectric constant. The fact is that the presence of large dielectric losses in an electrically insulating material causes strong heating as a result of which the material can be subjected to thermal destruction. In addition, if the dielectric is used in the oscillatory circuit, then dielectric losses prevent the achievement of high $\mathrm{Q}$, since with increasing equivalent resistance of the loss loop, damping of the oscillations in the circuit is amplified.

Taking into account the above, the experimental results obtained make it possible to assert that annealed bentonite can be used with great success for practical application, 
namely, for manufacturing high-voltage and high-frequency devices. Actually, as seen from Fig.1, 2 in the samples studied dielectric constant and dielectric losses decrease with increasing annealing temperature. At the same time, the permittivity value is 1300 , and the dielectric loss is 3 times, respectively. In addition, the value of the electrical resistance increases by 4 orders, the quality factor increases by100 times.

\section{CONCLUSION}

The influence of the annealing temperature on the electro physical parameters and IR spectra of unmodified bentonite was determined experimentally. It is established that as the annealing temperature increases, the dielectric constant, electrical conductivity and dielectric loss coefficient decrease, and the electrical resistance increases. The reason for the established facts, along with other factors, is a reduction in the percentage of polar compounds $\left(\mathrm{H}_{2} \mathrm{O}, \mathrm{OH}\right.$ groups, etc.) participating in the conductivity with increasing annealing temperature.

\section{REFERENCES}

[1] Л.Бесланеева, М.Х. Лигидов, А.К. Микитаев, Ю.И. Мусаев, С.И.Пахомов, С.Ю.Хаширова "Разработка новых органоглин, для получения полимерных нанокомпозитов с регулируемыми свойствами " Известия вузов. Химия и химическая технология. 2011. - T. 54. № 5. - C. 86-88.

[2] S. Wang, Y. Hu, L. Song, Z. Wang, Z. Chen, W. Fan. "Preparation and thermal properties of ABS/montmorillonite nanocomposite "Polym.Degrad. Stab. - 2002. - V. 77. - P. 423-426.

[3] J.C. Huang, Z.K. Zhu, X.D. Ma, X.F. Qian, J. Yin." Preparation and properties of montmorillonite/organosoluble polyimide hybrid materials prepared by a one-step appro ". Journal of Materials Science. - 2001. - V. 36. - P. 871-877.

[4] Gilman, J.W. Nanocomposites:" A revolutionary new flame retardant approach ". SAMPE J. - 1997. - V. 33. - Р. 40-46.

[5] Михайлин Ю.А. "Термоустойчивые полимеры и полимерные материалы ".СПб.: Профессия, 2006. - 623 с.

[6] J. J. Tunney, C. Detelliera. "luminosilicate nanocomposite materials. poly (ethylene glycol)-kaolinite intercalates " Chem. Mater. - 1996. V.8. - P. 927-935

[7] Ш.М.Гасанли, С.Р.Иманова, "Электрофизические характеристики композитных нелинейных резисторов на основе полимера и бентонита "Электронная обработка материалов, 2017, 53(4), p. 85-89.

[8] Першин Е.Д., Карпушин Н.А., Каздобин К.А. "Проводимость алюмосиликатов в присутствии воды. Электронная обработка материалов "2010, №4, с-60-67.

[9] Хаширова С.Ю., Бесланеева З.Л., Мусов И.В., Мусаев Ю.И., Микитаев А.К. "Спектральное исследование взаимодействия акрилата и метакрилата гуанидина с монтмориллонитом " Фундаментальные исследования. - 2011. - № 8-1. - С. 202-206;

[10] Т.Л.Ракитская1,Т.А.Киоселев,А.М.Джига."ИК-спектральное исследование структуры бентонита".Вестник Одеского Политехнического Университета. Химия том 17 выпуск 1(42) 2012 стр.13-19

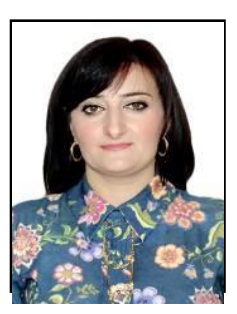

Sevinj Imanova was born in Georgia, 11.21.1981 Education - 1999-2003 Azerbaijan, Baku State University, student. 2003 - diploma in physics.

2003-2005. Azerbaijan, Baku State University, master's degree. 2005 - Diploma in Physics (Thermal and Molecular Physics).

Employment: 2005 - present time Ganja State University, Faculty of Physics and Technical Subjects, Lead Dispatcher in Physics.

Researches area: -physics of semiconductor research, other fields. Magnetic and electrical characteristics of composites based on modified with magnetic particles bentonite (DS) and polyethylene Published articles -6 articles.

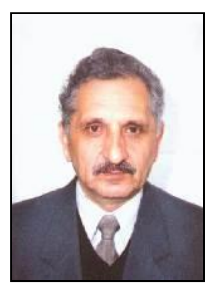

Shamistan Hasanli was born in Georgia, 12.15.1939

Education - 1957-1962-Leningrad (Sankt-Peterburg) State University, student. 1962-Diploma (MS) in Physics.

1967-1971 Postgraduate Physics - technical Institut A.I.Ioffe Leningrad (Sankt-Peterburg

1972-Diploma of Candidate of Sciences (Ph.D.), Baku, Institute of Physics of the Azerbaijan National Academy of Sciences

2005-Diploma of Doctor of physical-mathematical Sciences, Baku, Institute of Physics of the Azerbaijan National Academy of Science.

Employment: 1992-Present Institute of Physics, Leading Scientific Researchers Baku.

Memberships-2002 - Present Member of the Science-Technical Council of Institute of Physics.

Researches area: -Physics of Semiconductors-research, other fieldsInvestigation processes inversion channels of the MIS -structure on the basis of silicon and compound $\mathrm{A}^{3} \mathrm{~B}^{5}$.current research interest- Technology of ceramics materials on the basis $\mathrm{ZnO}$.

Published articles -160 articles and 8 patents.

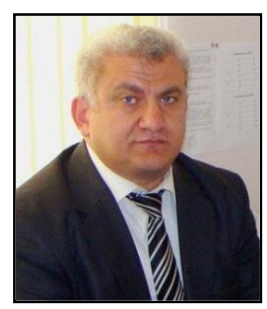

Rasim Huseynov was born in Vardanes 1971 Education - Physics, Ganja State Pedagogical Institute, Ganja (1994), 2012- Doctor of Phylosophy (Ph.D)

Researches area- The study of the physical properties of single crystals of silicon and structures based on them

Employment: Ganja State University, Faculty of Physical and Technical Subjects, assistant professor.

Published articles-30 articles .

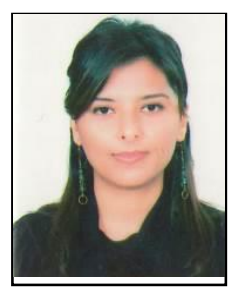

Samedova Ulkar Farruk was born in 03.12.1984 in Azerbaijan.

Education - Physics, Baku State University, Baku (2001-2005)

Azerbaijan Graduate student, Molecule and atom Physics, Baku (2005)

2014- Doctor of Philosophy (Ph.D.).

Researches area- Investigation of the composite materials based on dielectric, semiconductor and conductive matrix with the micro magnetic nanoparticles exhibits a number of unusual properties of the galvanomagnetic. Investigation of such composite systems in a magnetic field is of interest, both fundamental and practical point of view. By changing the conductivity of the matrix, and the size and concentration of the micro-nanoparticles it is possible effectively manage the sign and magnitude of the magnetic-field dependence of the magnetoresistance. This way you can obtain composites exhibiting a giant, colossal, tunneling, isotropic or anisotropic nature of the magnetoresistive effect (MRE), and to identify the main physical mechanisms of current flow in them. Obtaining radar absorbing materials

Employment: Institute of Physics, Leading Scientific Researches, Baku (2007), Postgraduate student (2008-2014).

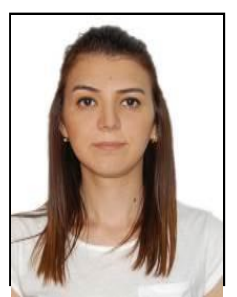

Safarzade Ulviyye

Place and date of birth - Azerbaijan

Education - Physics, Baku State University, Baku(2009-2013)

Graduate student, Astrophysics, Baku (2013)

Researches area- Magnetic, optic and electric properties of thin-film composite resistors based on Nano magnetic materials

Employment: Institute of Physics, Scientific Researches, Baku (2016),

Published articles- 4 articles. 